\section{Raízes}

Vol. 21, $\mathrm{N}^{0} 01$, jan.-jun./2002

E $\mathrm{n}$ s a $\mathrm{i}$ o
Michael R. Redclift ${ }^{1}$

Professor do King's College, Londres - Inglaterra.

\title{
PÓS-SUSTENTABILIDADE E OS NOVOS DISCURSOS DE SUSTENTABILIDADE
}

\author{
Tradução: Lemuel Guerra²
}

\begin{abstract}
RESUMO
A idéia central deste artigo é a de que neste momento no qual os discursos de sustentabilidade atingiram o centro da política ambiental internacional, é hora de dar uma pausa e examinar mais detalhadamente a agenda política e intelectual que eles propõem. Com este objetivo, examinamos neste trabalho os discursos através dos quais a sustentabilidade, e os direitos à natureza e os direitos da natureza, são expressos, sugerindo que a sustentabilidade, como um conceito estabelecido, tem freqüentemente disfarçado, em vestimentas mais novas, alguns velhos conflitos do passado. Defendemos também que a sustentabilidade tem, até agora, sido uma propriedade de diferentes discursos que estavam em luta. Somente a exposição dos pressupostos e conclusões desses discursos pode nos ajudar a clarear as escolhas e compromissos que envolvem a política ambiental e a abordagem das ciências sociais ambientais.
\end{abstract}

Palavras-chaves: Desenvolvimento Sustentável; Engenharia Genética; Sociedade de Rede.

\section{ABSTRACT}

In this article we argue that at this moment in which sustainability discourses reached the center of international environmental policy, it is time to examine more deeply the political and intellectual agenda proposed by those discourses. In this work we examine the discourses through which sustainability and the rights to nature and the rights of nature have been expressed, suggesting that "sustainability" has often masked, by using new dresses, some old conflicts. We argue as well that sustainability has been until now a property of different and contradictory discourses. We think that only exposing premises and outcomes of those discourses we can understand choices and commitments involved in environmental policies and the approach that social sciences have done on the environmental questions.

Key words: Sustainable Development; Genetic Engineering; Network Society.

\section{A SUSTENTABILIDADE DESDE A ECO-92}

Há tempos que a "sustentabilidade" tem existido sempre entre aspas. O poder desse conceito parece estar mais nos discursos que o cercam do que em qualquer valor heurístico ou substantivo partilhado que possa ter. Faz sentido, portanto, examinar esses discursos mais detalhadamente. A tese que defendemos neste trabalho é a de que a idéia de sustentabilidade ainda é útil, mas que não deve se as- sociar unicamente à "natureza exterior”. As mudanças nas comunicações globais e na genética têm alterado tão substancialmente nossas relações com o meio ambiente, que seria pouco produtivo inscrevê-las fora da "natureza" que descrevemos como "sustentável”. No século XXI, faz sentido considerar-nos como parte do discurso da sustentabilidade.

A re-emergência da economia de mercado e das políticas neoliberais nos anos 80 do século passado, com a qual

${ }^{1}$ Michael Redclift tem-se destacado pela sua voz dissonante no campo do debate sobre o Desenvolvimento Sustentável. Já no seu livro de 1984, significativamente intitulado Desenvolvimento Sustentável: explorando as contradições, o autor chamava a atenção para a necessidade de pensar os problemas ambientais em articulação com o sistema econômico global e com as estruturas políticas. Mais recentemente, tem proposto o conceito de pós-sustentabilidade, como uma contribuição para a reflexão sobre os limites do modelo de Desenvolvimento Sustentável, que ficam gradualmente mais evidentes.

${ }^{2}$ Professor do Programa de Pós-Graduação em Sociologia, UFPB/UFCG

(e-mail: lenksguerra@yahoo.com). 
a discussão sobre a sustentabilidade é associada, é um claro divisor de águas para a política ambiental. De maneira cada vez mais freqüente, a "sustentabilidade" foi se separando do meio ambiente e foi confundida com as questões mais amplas da eqüidade, governabilidade e justiça social, o que serviu para transferir a discussão política para diferentes lugares. A “sustentabilidade” foi, então, usada como um sufixo para quase todas as coisas julgadas desejáveis.

As primeiras discussões sobre a "sustentabilidade" e sobre o "desenvolvimento sustentável" se preocupavam de modo particular e não exclusivo com as necessidades humanas. A partir de 1980, o debate sobre a temática da sustentabilidade se fortaleceu, sendo muito influenciado pela economia neoclássica, o que se refletiu na tentativa de traduzir escolhas ambientais por preferências de mercado, seguindo a ortodoxia neoliberal. A crescente atenção dedicada à construção de sistemas de medição capazes de avaliar a situação das variáveis ambientais foi um corolário necessário dessa tendência, emergindo uma busca acentuada de maneiras práticas pelas quais a sustentabilidade pudesse ser construída, através da inserção da preocupação ecológica no âmbito das políticas e nos planejamentos estatais. A disseminação dos sistemas de medição acima mencionados ampliou o uso de que foi objeto o termo "sustentabilidade", e abriu um novo discurso sobre desenvolvimento, com um grande apelo aos tecnocratas e aos empresários.

Talvez em resposta à incorporação da economia ambiental às políticas mais centrais ou para compensar o negligenciamento, muito da discussão sobre a sustentabilidade como um processo político foi feito por outras disciplinas que não a economia ambiental. Uma conseqüência disso foi o distanciamento, quase imperceptível, da discussão mencionada em relação ao tópico das necessidades humanas, que foi a preocupação original da Comissão Brundtland, e sua aproximação do tópico dos direitos. A ênfase tanto nos direitos humanos como nos direitos não-humanos, por sua vez, dirigiu a discussão referente à sustentabilidade para outras preocupações mais “ortodoxas" das ciências sociais: as questões do poder, da distribuição e da eqüidade.

Neste artigo, argumentamos que as ligações entre o meio ambiente, a justiça social e a governabilidade têm se tornado crescentemente vagas em alguns discursos de sustentabilidade, e que as relações estruturais entre o poder, a consciência e o meio ambiente têm sido, gradualmente, obscurecidas. Temos também observado que, na busca de uma visão mais inclusiva da sustentabilidade, a retórica política tem, freqüentemente, secundarizado a discussão sobre as questões ambientais.

A principal corrente do debate sobre a sustentabilidade originou-se nos grupos ambientalistas, caracterizados por se distanciarem das soluções neoliberais para os problemas ambientais e sociais. Todavia, argumentaremos no sentido de que os discursos ambientais que reivindicam a precedência dos "direitos", e que são conduzidos em altos níveis de abstração e de agregação geográfica, estão, em seus fundamentos, apenas frouxamente ligados às escolhas culturais e decisões políticas. Ao mesmo tempo, a crítica à economia de mercado, que tem caracterizado as Organizações NãoGovernamentais (ONG's) internacionais, apresenta problemas em si mesma. A oposição ao neoliberalismo é mais efetiva quando vai além da crítica às instituições, incluindo as novas redes de comunicações globais. Isso ficou evidente na oposição "virtual”, mas muito clara e efetiva, à Organização Mundial do Comércio (OMC), manifestada na conferência de Seattle, em 1999, e nos protestos de rua em Washington, Praga e na Holanda, em 2000.

Esses discursos “oposicionistas” de inspiração ambientalista representam a comunicabilidade de diferentes códigos, mas freqüentemente dependem da mesma terminologia formal que cerca a sustentabilidade. Eles marcam práticas de comunicação que carregam, em si mesmas, significados simbólicos e políticos - referências a um "poder democrático", à “autonomização”, à “justiça natural” -, vistos pelos seus defensores como uma alternativa à falência da democracia representativa (ESTEVA, 1999). As referências acima citadas, centrais nos novos discursos de sustentabilidade, têm uma ligação pouco consistente com os desdobramentos da política ambiental. Todavia, desde a ECO-92, esses novos discursos ambientais refletem as mudanças da globalização, na genética e nas comunicações, e demonstram, vivamente, a importância das novas desigualdades espaciais. Nesse sentido, eles podem ser definidos como discursos da "pós-sustentabilidade".

Há outras fontes de inquietação no terreno da "sustentabilidade": a chave para entender os novos discursos elaborados sobre essa temática está em seus significados simbólicos, mas também nos avanços tecnológicos na área das comunicações. O principal exemplo, que discutiremos posteriormente neste trabalho, é o da INTERNET. Outro exemplo é o da recente revolução observada tanto na genética humana quanto na genética em geral. Ao mesmo tempo em que as comunicações globais estão sendo revolucionadas, mudanças radicais têm ocorrido na "na- 
tureza”. As fronteiras entre espécies têm sido subvertidas e a "nova biologia", aliada à revolução nas tecnologias da informação, está alterando a definição tradicional de "indivíduo” e de sua participação nas sociedades civis.

O desafio formal representado pela Conferência da Terra (RIO-92) não passou de um acordo, envolvendo o sistema de governo global, a respeito de novos princípios de sustentabilidade, que pressupunha um meio ambiente global e um conjunto de instituições que o exploravam e o administravam. Porém, durante a última década, o sistema global alargou-se e se reconstituiu. Instituições como a Organização do Comércio Mundial, o Projeto Genoma Humano e a $W E B$, foram a ele integradas, sendo tão globais quanto a Organização das Nações Unidas.

Nesse novo sistema global de territorialidade, a propriedade do meio ambiental não é mais necessária, mas apenas uma marca condicional. Não é mais apenas um território comum, que mantém as pessoas juntas, no qual reivindicações de direitos universais são feitas para todos. As persistentes reivindicações de que os direitos "naturais" sejam protegidos, e de uma melhor governabilidade do meio ambiente, precisam ser localizadas em um novo contexto, no qual tanto as escalas da justiça têm se alargado, quanto a "sustentabilidade" demonstra ser uma propriedade de discursos diferentes e opostos. Neste trabalho, argumentamos que, antes de podermos explicar completamente muitas das questões que cercam a sustentabilidade, devemos desvendar alguns dos discursos que têm modificado seu sentido. Inicialmente, vejamos os relacionados à "globalização".

\section{DisCURSOS DA GLOBALIZAÇÃO}

De acordo com Castells (2000), a globalização está ligada a um novo paradigma tecnológico, cujas raízes estariam na microeletrônica, nas novas tecnologias informacionais de comunicação e na engenharia genética. Os dois elementos-chaves desse paradigma seriam, para este autor, a comunicação interativa... e a criação e a manipulação de organismos vivos, incluindo partes do corpo humano (Castells, 2000: 10). Essas mudanças estão destinadas a penetrar todos os domínios do nosso sistema eco-social, através do desenvolvimento de códigos instrumentais e correntes culturais incluídos na articulação glo- bal, os quais constituem o que Castells chama de sociedade de redes. A "nova economia” é, de acordo com esse autor, informacional, globalizada e em rede.

As transformações às quais Castells se refere, colocam o meio ambiente no centro da globalização, já que, de um lado, a natureza material é "manipulada" e "modificada", e, por outro lado, a "natureza" simbólica é interativa, local e universalmente comunicada. O estabelecimento dos regimes ambientais, desde a Conferência da Terra em 1992, provê exemplos de ambos os processos citados.

A Declaração do Rio/92 - a Agenda 21 - refletiu uma crescente preocupação com as questões ambientais, a qual levou ao estabelecimento de um conjunto de mecanismos institucionais internacionais ${ }^{3}$ a fim de assegurar que os problemas do meio ambiente fossem tratados de maneira mais eficiente. Por trás dessa preocupação estavam alguns pressupostos. O primeiro pressuposto foi o de que os problemas ambientais internacionais - notadamente a mudança climática e a perda da biodiversidade - eram "anomalias das relações existentes entre política e ciência e da capacidade destas de lidar com os problemas ecológicos” (BECKER, JAHN \& STEIS, 1999: 284, itálico de Redclift).

O segundo pressuposto, que orientou a Conferência da Terra, de 1992, foi o de que os países do Norte e os do Sul têm um interesse comum de assegurar que o desenvolvimento econômico futuro não seja prejudicial ao meio ambiente. Num determinado nível, essa abordagem normativa foi muito atraente, pois ela marcou a superação de divisões antigas, especialmente pós-1945, e um reconhecimento da vulnerabilidade do planeta. Essa abordagem do "consenso liberal" ainda representa o discurso dominante em torno de conceitos chaves, tais como os de "desenvolvimento sustentável”, "segurança humana” e "mudança ambiental global".

Segundo Law \& Barnet (2000: 55), a globalização "constrói o presente como um momento que é parte de uma transformação histórica fundamental e tem se tornado a grande narrativa que justifica o fim de qualquer outra referente à mudança social”. A globalização, portanto, toma sobre si o manto da modernidade, que alude, simultaneamente, tanto à viagem quanto ao destino por ela desencadeados.

$\mathrm{Na}$ perspectiva do novo século, os discursos políticos desse tipo são suportes ideológicos essenciais para uma

${ }^{3}$ Os problemas ambientais têm aludido ao sistema internacional, já que não foram previstos (pelo menos os principais) e foram de difícil controle através dos instrumentos das instituições financeiras. 
ação articulada por governos nacionais e organizações internacionais (BAUMANN, 1998). Esses discursos traduzem idéias tais como a de "sustentabilidade", para o terreno lingüístico, gerando uma sintaxe que normalmente não se encontra na diplomacia internacional. Eles também abrem oportunidades para diferentes atores e grupos se mobilizarem em torno de políticas e, durante o processo, lhes darem legitimidade. Os diferentes atores são também capazes de elaborar e articular esses discursos, criando maneiras de refiná-los ou de modificá-los. Essas narrativas discursivas são, de um lado, a matéria-prima da atual política ambiental internacional, e, por outro lado, são negociadas e trocadas em distintos níveis espaciais.

Para citar um exemplo comum: dentro da conservação internacional do meio ambiente, a palavra "natureza" é usada para expressar os interesses sociais, econômicos e ambientais. Os conservacionistas a usam significando um “objeto", tal como um habitat, um campo, uma floresta, um pântano ou um conjunto de corais. Grupos ambientalistas, todavia, também têm adotado a palavra "natureza”, para expressar identidades locais e seu próprio meio ambiente (natural) legítimo. Finalmente, "natureza” é usada em discursos políticos para expressar um julgamento profissional sobre o tipo ou valor de um recurso - "capital natural crítico", "nichos de biodiversidade”, “cadeia de recursos", "bacias naturais", dentre outros. Cada uma dessas definiçõoes de natureza provê significados diferenciados para diferentes grupos de pessoas e reflete seus diferentes interesses.

De modo semelhante, no caso do gerenciamento de florestas tropicais, podemos identificar discursos e alianças muito contrastantes, através dos quais a natureza é caracterizada e os objetivos de conservação são expressos, de maneira que os interesses dos grupos envolvidos sejam, de um modo ou de outro, contemplados. Proteger a "natureza" torna-se sinônimo de proteger o meio ambiente, os sistemas ecológicos em risco, bem como as "populações indígenas e locais” que habitam esses ambientes. Também não é totalmente claro em que esses interesses se sobrepõem ou divergem.

Há outra faceta dos novos discursos em torno da natureza à qual pouca atenção tem sido dada. Sob a globalização, os discursos narrativos freqüentemente obscurecem os processos sociais espacializados, que removem e redirecionam recursos biológicos de um lugar para outro. As florestas tropicais se tornam, literalmente, um recurso global, para ser explorado por vários agentes, no interesse da "ciência", bem como no do mercado. Antes da mer- cantilização dos benefícios da biodiversidade, eles precisam ser, primeiramente, privatizados, e sua propriedade claramente estabelecida. Este é o importante e altamente contestado domínio dos direitos da propriedade intelectual, o qual, de acordo com McAfee (1999), é construído sobre areias movediças. Ao contrário da premissa do paradigma econômico global, não pode haver uma medida internacional para comparar e trocar valores reais da natureza entre diferentes grupos de diferentes culturas, e com amplos e também diferentes graus de poder econômico e político (op. cit.: 133).

As mudanças sócio-econômico-políticas atualmente em curso acarretam claras conseqüências em termos de relações de poder em nível mundial. Os processos, através dos quais a globalização ocorre e os acordos ambientais são firmados, envolvem sistemas de informação e de capital altamente desiguais, aos quais grupos de pessoas e governos têm um acesso altamente desigual. Vogler é um dos exemplos de como alguns autores denunciam as estruturas desproporcionais de poder, em cujos âmbitos são decididos os rumos da constituição de uma economia e de um meio ambiente globalizados: "Na maioria dos regimes ambientais vigentes há uma clara evidência da maneira pela qual as normas e regras emanadas das práticas e legislações dos Estados Unidos são traduzidas para o nível internacional" (VOGLER, 2000: 209).

É um paradoxo da globalização o fato de que as deliberações que acompanham as decisões de exploração de material biogenético, por exemplo, serem raramente de caráter público, no sentido em que eram as decisões políticas no passado. Isso tem gerado um certo desconforto e produzido, por sua vez, novas formas sociais de protestos, bem como novas práticas de legitimação.

\section{REGIMES AMBIENTAIS INTERNACIONAIS}

Dentro da tradição realista das relações internacionais, podemos distinguir outras práticas discursivas. Depois de 1992, novos regimes ambientais internacionais foram estabelecidos para ajudar a implementar os princípios do Desenvolvimento Sustentável (op. cit.). Esses regimes são processos legais, institucionais e políticos, funcionando como garantia para a natureza ubíqua dos discursos de alianças. Atualmente, existem centenas de regimes ambientais, procurando regular, ou controlar, virtualmente, todas as facetas do ambiente natural, a fim de favorecer os objetivos e interesses de diferentes coalizões de grupos sociais. 
Todavia, a efetividade dos novos regimes ambientais depende, em grande medida, da maneira pela qual esses são percebidos por uma grande variedade de grupos interessados. Vogler argumenta nesse sentido:

... observando o processo de expansão dos regimes comuns, uma hipótese parece prover a melhor explicação para a incidência de instituições eficientes e bem-desenvolvidas. Há uma clara relação entre a vulnerabilidade mútua, a interdependência e a efetividade dos regimes ambientais (op. cit.: 208).

Para ajudar na aceitação e legitimação dos regimes ambientais, um conjunto de medidas é tomado para prover incentivos e obstáculos para a implantação dos regimes. Essas medidas incluem o perdão de dívidas externas, a transferência de tecnologia e "trocas" internacionais, tais como incentivos fiscais ou o reflorestamento. Tais medidas constroem uma armadura de "leis suaves", adotadas para compensar "distorções" globais e a desigualdade tanto entre nações quanto dentro delas. Como sugerido antes, as medidas mencionadas são uma conclusão lógica da visão de que as desigualdades globais são "distorções", "aberrações" do sistema global, e não conseqüências deste.

A existência de "regimes" ambientais internacionais também serve para obscurecer algumas marcas-chaves da nova política ambiental global. Por trás da fachada dos acordos ambientais mundializados, existem as questões fundamentais da justiça e da eqüidade, que os regimes em si mesmos não abordam. O que constitui um nível "justo" de emissão de carbono? Deveriam os cortes nos níveis de emissão ser iguais, em todos os lugares do planeta? Deveriam eles estar ligados à variável do desenvolvimento econômico?

Há uma falha ainda maior nos regimes ambientais internacionais que surgiram durante a última década. Embora argumente-se que a "lei suave", instituída através desses regimes, contribui para uma pedagogia social, engajando todos no processo, instaura-se o risco de que se enfraqueçam as obrigações internacionais existentes, particularmente aquelas referentes ao mundo industrializado. Quanto mais a "consulta" para que se assinem acordos e se estabeleçam convenções conduz à não aceitação por parte de alguns países, menos as sanções legalmente instituídas são aplicadas. A ilusão da negociação e a legitimação do expediente da "aceitação" asseguram que a distribuição de poder existente no sistema global não seja nem confrontada nem desafiada.

Raízes, Campina Grande, vol. 21, nº 01, p. 124-136, jan./jun. 2002

\section{A SEGURANÇA HUMANA E O MEIO AMBIENTE}

Ao lado dos discursos da globalização e dos regimes ambientais internacionais, o interesse pela "segurança humana" tem ampliado a abrangência do discurso do desenvolvimento sustentável, provendo o suporte ético necessário às políticas ambientais globais. Muitos dos símbolos desse discurso são exemplificados pelo então Vice-Presidente dos EUA, Al Gore, ao defender o "Plano Marshall Global”: “... a tarefa de restaurar o equilíbrio natural do sistema ecológico da Terra... pode ser vista como uma nova missão do interesse na "justiça social", na democracia e na liberdade de mercado da América..." (GORE, 1992: 270). Como vemos, essas palavras significam que o meio ambiente se transforma num instrumento para atingir outros objetivos, de natureza social e política (a democracia liberal). A defesa do cuidado e da proteção do ecossistema da Terra alude a propriedades universais (que ele chama de "equilíbrio natural"), ao invés de mencionar os valores políticos que lhe subjazem.

Há seis pontos principais no "Plano Marshall" de Gore: a estabilização da população mundial; o desenvolvimento de tecnologias apropriadas; as técnicas da avaliação ecológica; o melhoramento de esquemas regulatórios; a reeducação da população global sobre as necessidades ambientais e o estabelecimento de modelos de desenvolvimento sustentável. Os críticos de sua abordagem argumentam que

... produzir discursos ecológicos, articular planos de desenvolvimento sustentável e propagar definições literárias de meio ambiente para os indivíduos contemporâneos, simplesmente adiciona novos reforços ao padrão muito específico de formação do estado,... a matriz moderna da individualização (LUKE, 1999:149).

Todavia, o significado político dos discursos da globalização não se confina no nível individual. O meio ambiente, visto como um recurso estratégico, pode ser gerenciado da mesma maneira como foi o status de "não-aliado", durante a Guerra Fria. Para aumentar a segurança humana, organizações supranacionais podem ser vistas como operando favoravelmente ao "interesse global", já que a estabilidade ambiental é percebida como um problema "compartilhado" tanto pelos países do Norte quanto pelos do Sul. O discurso da segurança do planeta, ou da segurança humana, é um dos mais qualificados suportes para intervenções, apresentadas como necessárias para reduzir as vulnerabilidades ambientais, na medida em que 
nele é obnubilada a natureza política dessas intervenções. Um princípio do novo “ambientalismo global” é, então, o papel atribuído aos Estados e a instituições supranacionais. Sob essa perspectiva, categorias como as de "sistema ecológico" e de "meio ambiente”, deixam o domínio moral, e se transformam em coisas que instituições supra-estatais devem administrar, observando-se um distanciamento do que se conhecia como o princípio da soberania nacional, defendido pelos teóricos da tradição realista das relações internacionais.

Concomitantemente, o novo paradigma no campo do ambientalismo global advoga uma divisão da responsabilidade pelo meio ambiente. As ideologias da "parceria" enfatizam os benefícios de um melhor gerenciamento dos recursos naturais, tanto para "populações em risco" quanto para os ecossistemas. Finalmente, embora o discurso da segurança ambiental parta, aparentemente, da lógica do Estado Nacional, defendida pela escola realista, é construído diferentemente, a partir do consenso liberal do pósguerra, proporcionando um tipo de neo-keynesianismo para o meio ambiente, baseado no planejamento e na intervenção internacional. Termos tais como "uso racional", "gestão ambiental" e "direitos soberanos de propriedade" fazem os princípios da ecologia ressoarem apropriadamente para públicos específicos, particularmente aqueles da América do Norte, sendo também defendidos como aplicáveis para todo o mundo.

Antes de examinar algumas das maneiras pelas quais a materialidade e a consciência estão mudando os discursos e as políticas globais, nos dedicaremos a analisar em que medida o peso do "meio ambiente" - e, em particular, do "gerenciamento da natureza" - é afetado, quando relacionado com outros fatores.

\section{O GERENCIAMENTO DA NATUREZA E A JUSTIÇA AMBIENTAL}

Uma das propostas afirmadas nos acordos internacionais pós-RIO/92 é a de que a "avaliação científica" levaria à constituição de um melhor perfil de áreas e espécies protegidas. A Agenda 21 registra que “... fortalecendo a base científica do gerenciamento sustentável e melhorando o conhecimento científico... estaria se constituindo uma capacitação e capacidade científicas” (AGENDA 21, 1992).

Isso, por sua vez, tem levado a crescentes esforços para proteger o meio ambiente através de acordos firmados no nível internacional. Um exemplo disso é a Declaração
Universal das Responsabilidades Humanas, preparada pela 53ª . Assembléia Geral das Nações Unidas, em conjunção com a comemoração dos 50 anos do aniversário da Declaração dos Direitos Humanos das Nações Unidas. Dois dos 19 princípios da Declaração Universal das Responsabilidades Humanas, referem-se particularmente ao meio ambiente:

Artigo 7: Todos os povos têm a responsabilidade de proteger o ar, a água e o solo da Terra para o bem das gerações presentes e futuras;

Artigo 9: Todos os povos devem promover o desenvolvimento sustentável em todo o mundo, para assegurar dignidade, liberdade, segurança e justiça para todos.

Westing (1999) argumenta que a Declaração Universal das Responsabilidades Humanas das Nações Unidas deveria ser uma

... convenção obrigatória em muito menos que os 18 anos levados pela Declaração dos Direitos Humanos das Nações Unidas (1948-1966), e que o Tratado Mundial pela Natureza (1982) deveria ser transformado numa... convenção obrigatória, com garantias explícitas para os direitos apropriados da natureza per se (op. cit.: 157).

$\mathrm{Na}$ verdade, ambas as questões - a base científica do discurso da "sustentabilidade" e o uso desse discurso a favor dos "direitos naturais" - requerem uma maior atenção. Mal-entendidos, absolutamente centrais nessa área, têm espalhado uma significativa confusão.

\section{A BASE CIENTÍFICA PARA O MANEJO DO MEIO AMBIENTE}

A crença numa ciência "global”, implícita na Agenda 21, é altamente contestada, não apenas por muitos cientistas. O que tem sido proposto para solucionar os problemas globais é uma combinação de tradições científicas variadas e descontínuas, cujas raízes se encontram em diferentes corpos teórico-disciplinares. Por exemplo, a química ambiental é usada para pesquisar a poluição, na mesma medida em que o conhecimento de botânica é usado para identificar espécies em perigo de extinção... Essas tradições habitualmente insistem que estão esculpindo a natureza conjuntamente, embora obedecendo a fronteiras que já existem no mundo natural.

Muitas das diferentes disciplinas não têm nada a dizer sobre essas questões-chave, corretamente identificadas na 
Agenda 21 como ligações entre o sistema ambiental humano e o natural, não sendo nem prescritivas nem preditivas. A idéia de "sustentabilidade" é evocada em discursos políticos que aludem ao método objetivo científico, sem as complicações do julgamento humano. Na prática, isto é rotineiramente usado como uma maneira de guiar as ações humanas. A parte central da tradição científica, que tem impulsionado progressivamente as fronteiras heurísticas do conhecimento, tem imposto limites, categorias e taxonomias à natureza, usados para fazer julgamentos que refletem as preocupações humanas e interesses políticos.

O manejo da natureza e dos recursos naturais, então, é ligado mais às questões das necessidades e valores humanos do que a uma compreensão científica abstrata. Às vezes, de modo usual, é afirmado por estrangeiros "desinteressados" que a "comunidade local" deveria ser a unidade de manejo nas áreas protegidas, já que esses grupos se adequam às funções ecológicas "naturais". Por exemplo, os caboclos amazônicos são interpretados como um ingrediente essencial para reconciliar a extração e manejo florestais, uma vez que esses grupos são habitantes naturais da região Amazônica.

Todavia, como uma recente abordagem de Browder (1995) afirma, a respeito do desmatamento na América Latina, que os paradigmas globais devem ser usados para analisar os problemas ambientais locais a partir das preocupações especificamente globais. O desmatamento é "compreendido" em termos das teorias genéricas do desenvolvimento e do meio ambiente, quer sejam as neoclássicas, as neomalthuseanas ou as derivadas da economia política. O autor conclui que "... é útil que as variações do 'local' sejam pensadas sob a ótica dos padrões globais” (op. cit.: 135). Ao nosso ver, os discursos globais sobre o meio ambiente e sobre a sustentabilidade são, desse modo, usados para obscurecer as evidências e, devido à dificuldade do entendimento, tais discursos fornecem poucas dicas para a compreensão e respeito dos significados variados da degradação ambiental.

De maneira similar, muito da retórica que acompanha a sustentabilidade falha em reconhecer que os objetivos ambientais e sociais são, freqüentemente, diferentes e, às vezes, contraditórios. Essas contradições são expressas e freqüentemente formuladas por seções dos "lobbies" dos financiadores, na visão de que o super consumo no Norte é responsável pela maioria dos problemas ambientais (REDCLIFT, 1996). Tal visão não considera as políticas e tecnologias que encorajam o mau uso, a superprodução

Raízes, Campina Grande, vol. 21, nº 01, p. 124-136, jan./jun. 2002 de hidrocarbonos, a inabilidade para reciclar o lixo e a recusa para contabilizar os custos ambientais externos. Por outro lado, também há um perigo real inerente à ausência de crítica quanto ao super consumo no Norte e relativo à falha em olhar por trás do comportamento consumista, não considerando desta forma o fato de que muitas pessoas, no Sul como também no Norte, dificilmente levarão a sério o que vêem apenas como uma prescrição moral para se comportarem diferentemente. Culpar indivíduos pelos seus comportamentos de consumo sem tentar compreendê-los em seu contexto social é como culpar os jovens pela sua incapacidade de dizer "não às drogas", sem considerar a conjuntura em que os usos de drogas emergem.

\section{OS “DIREITOS” DA NATUREZA E O MEIO AMBIENTE}

A temática dos direitos da natureza permeia a crescente literatura sobre "direitos" e o meio ambiente, como alguns comentadores têm notado (DOBSON, 1998; MILLER, 1998). Atualmente, os "direitos da natureza” são, usualmente, traduzidos como "direitos humanos". A idéia de que a natureza nos dotou de direitos naturais e inalienáveis, dos quais os governos, em alguns casos, querem nos privar, é profundamente inspirada pela consciência política, estando já na Declaração Universal dos Direitos Humanos da ONU, como temos visto, e tem uma história que remete à Declaração Francesa dos Direitos, de 1789, e à Declaração de Independência dos Estados Unidos, do ano de 1776.

O problema, porém, é que esse sentido dos "direitos", no contexto político, é derivado da lei natural, rotineiramente confundida, nos discursos ambientais, com as "leis da natureza”. Essas leis - o cânone da ciência - incluem a crescentemente contestada idéia de homeostase, tanto na Biologia quanto na Cibernética, e as leis da termodinâmica, que expressam o princípio de que os processos físicos são irreversíveis. Mais uma vez as leis são encaradas como "naturais", e como tais tendem a ser confundidas com as implicações políticas e sociais que se seguem à sua adoção (das leis). A sustentabilidade é um desses casos.

Dobson (1998: 241) nota que as teorias de sustentabilidade “... às vezes aparecem submetidas à justiça, mas freqüentemente observa-se o contrário, e a justiça fica submissa à sustentabilidade" Essa posição subordinada da justiça em relação à sustentabilidade é dissimulada pela linguagem da 'funcionalidade' e somente vem à tona 
quando a relação entre vencedores, comumente fundamentada em teorias do desenvolvimento sustentável, é substituída por uma relação vencedores-perdedores. Ela também vem à luz quando são examinados casos, lugares e comunidades atualmente existentes.

Dobson (op. cit.: 242) também observa que nem a sustentabilidade nem a justiça social têm significados fixos e claros, “...o que abre caminho para que um dos termos se legitime em relação ao outro...”. Se a sustentabilidade é vista como sustentação de propriedades e de pessoas, então a distribuição de recursos e de direitos entre eles é central para seus objetivos. Se, porém, a sustentabilidade é vista como proteção e conservação do meio ambiente, então a "justiça" consiste, primariamente, em assegurar que o ecossistema continue a desempenhar suas funções ecológicas vitais. Atualmente, não podemos saber se a justiça é uma condição necessária ou suficiente para a sustentabilidade ambiental.

No que concerne aos valores, então, a discussão da sustentabilidade e da justiça social raramente aborda as complexidades que cercam a questão. Analisando nove livros sobre o meio ambiente e o desenvolvimento na América Latina, Silva (1998:26) escreve que “... esses autores ancoram a interpretação do desenvolvimento sustentável numa concepção partilhada de justiça social. Para esses autores, a consecução do desenvolvimento sustentável está indissoluvelmente ligada à superação ampla da pobreza e da notória desigualdade”.

Neste contexto, o que se revela é um caso sério do que podemos chamar de discurso da disjunção, na medida em que se aceita a afirmação de que as pessoas de todos os lugares partilham a compreensão da justiça social, da mesma maneira como partilham a de sustentabilidade. Talvez este não seja o caso.

Em uma análise dos discursos sobre a floresta na África, Fairhead \& Leach (2000) comparam a visão iluminada e "ortodoxa" do manejo florestal com as visões dos povos do continente africano. Segundo a visão dos autores citados acima, a floresta é retratada como uma cobertura “original” e "natural”, que vem sendo destruída progressivamente pelo povoamento da terra e "... pela modernidade, que transforma culturas anteriormente favoráveis às florestas" (op. cit.: 43). Os autores citados contestam a visão dominante, afirmando que “... a persistência de tais representações, mesmo a despeito da existência de contrainterpretações e de evidências destas, sugere que uma certa "imposição está sendo exercida nos processos científicopolíticos” (idem). Eles atribuem a dominância da aborda- gem cientifíco-política a estruturas econômicas e administrativas, e aos mecanismos financeiros que operam dentro dos planos de desenvolvimento. O "discurso global” em torno do desmatamento é um exemplo do que se afirma como um "modelo de representação", do qual é difícil desembaraçar os argumentos ou as evidências. Em certas circunstâncias políticas, esses discursos têm "efeitos materiais" facilmente difundidos, sem que seus pressupostos sejam submetidos a nenhuma análise rigorosa.

É essa questão da "materialidade" e da consciência que discutiremos a seguir. Dois processos podem ser identificados como transformadores da materialidade do mundo e correspondentemente de nossa consciência. Eles estão produzindo tanto ambientes materialmente diferentes, bem como maiores mudanças na maneira pela qual os mesmos são socialmente construídos e representados.

\section{O SUJEITO HUMANO CONSIDERADO EM TERMOS DE 'GENES'}

O primeiro conjunto de mudanças está na Biologia, em geral, e especificamente na Genética. Num determinado sentido, as questões de "segurança" têm se transformado na direção da "natureza”, forçando-nos a reconsiderar o que temos significado tanto por "sustentabilidade" quanto por "segurança". Por exemplo, a proteção da natureza é agora usada para legitimar a ação militar e, como temos visto, afirmações a respeito dos objetivos da gestão racional da natureza têm se cristalizado em "leis suaves", promulgadas por governos.

A sustentabilidade não é mais primariamente uma questão de manter e aperfeiçoar os atuais recursos ambientais: trata-se agora de criar outros recursos. A publicação dos primeiros resultados do Projeto GENOMA HUMANO marca o divisor de águas no terreno do "tomado como dado" na Biologia, que dá suporte à maioria das políticas ambientais: a responsabilização individual, a cidadania e a governabilidade. A nova genética está alterando o que se conhece como vínculo social e como participação na sociedade civil. A questão que se impõe se refere a como fazer para "governar" um sistema global que é, na verdade, crescentemente extraterritorial!

Em seu novo e provocativo livro, Experiencing the New Genetics, Finkler (2000:199-200) escreve:

O Homem contemporâneo não é mais o político de Aristóteles, o racional de Descartes ou o animal cultural dos antropólogos. Ele é ape- 
nas um animal compreendendo específicas seqüências de DNA que o distinguem dos outros animais por um arranjo molecular muito suave... a visão científica e biomolecular dos humanos está indo na direção de uma concepção de nosso ser como animais programados, independentes da cultura e da moralidade: a prioridade tem sido dada mais à herança genética do que à cultural... a ideologia da herança genética priva a pessoa da propriedade de agente. A visão da genética é a de que os genes pré-determinam as pessoas... uma pequena elite pode ainda transmitir status, poder e riqueza para seus descendentes, mas cada vez mais, na contemporaneidade, predomina a visão de que a família e o parentesco é mais determinado pela herança de DNA do que por um senso de moralidade que se traduz em solidariedade, responsabilidade, obrigações e afeto.

Essa passagem nos alerta para dois processos através dos quais a "nova Biologia" está ganhando autoridade e plausibilidade. O primeiro se refere ao fato de que a genética atingiu um estágio que permite a recombinação dos indivíduos - a partir dos componentes do corpo. Isto está mudando o que conhecemos como ser "humano", por exemplo, pela diminuição das fronteiras entre animais irracionais e os humanos. Conceitos que vemos como inerentemente humanos, como os de identidade e de consciência, que dão suporte à aceitação dos direitos e das responsabilidades, aparecem, pela primeira vez, como infinitamente maleáveis. Os indivíduos humanos estão se tornando seres geneticamente planejáveis.

O segundo processo digno de nota, também capturado do trecho de Finkler (op. cit.), supracitado, é a maneira pela qual o discurso público está sendo modificado pela nova genética. A disseminação do conhecimento genético e o reconhecimento do poder determinativo da informação genética adquirem legitimidade e primazia no discurso político, antes reservadas aos direitos e obrigações sociais, no que se refere à teoria social. Em um certo sentido, a Biologia se torna a teoria social. Os processos tecnológicos implicados na nova genética têm servido para redefinir as relações entre os indivíduos e a sociedade, sobretudo pela mudança no que entendemos como indivíduo e, potencialmente, pela alteração na sua relação com a sociedade. No lugar da sociedade civil como terreno da negociação social, da confiança e dos direitos, podemos antecipar a alquimia dos indivíduos, o que seria a protogênese - em termos biológicos - da própria sociedade.

No seu livro Jamais fomos modernos, Latour destaca os fenômenos que nunca foram nem fatos sociais, no sentido durkheimiano, nem objetos naturais, “... mas emergem na intercessão das práticas sociais e nos processo naturais como formas socialmente construídas de mediação entre a sociedade e a natureza" (LATOUR, 1993: 11). Latour estava se referindo a fenômenos tais como a doença da “vaca louca” ou ao esquentamento global, que são híbridos, incorporando elementos materiais e socialmente construídos. No futuro, a genética humana, junto com outros processos sistêmicos, pode ser equilibrada para mudar o terreno, mesmo que posteriormente, na direção da mediação entre "natureza" e "sociedade", para o ponto no qual o híbrido não será nem mesmo percebido como política pública, tal como a questão do esquentamento global ou a doença da "vaca louca". O processo de mediação se completará quando fenômenos como estes forem menos reconhecíveis dentro do domínio público, ou do discurso público.

Já vivemos numa sociedade global na qual a seleção de um co-genitor pelas características genéticas é uma realidade, sendo nela as "mães de aluguel" comumente encontradas. A comunidade de pesquisa tem inserido a clonagem genética de animais na agenda política e os políticos, cautelosos com algo que eles não tinham pensado, têm reagido hesitantemente. Por sua vez, as propostas de clonar seres humanos a partir do DNA dos pais naturais têm atraído uma controvérsia internacional na Europa. O “patenteamento" da natureza in vitro tem provocado respostas contraditórias, já que isso parece dar às companhias transnacionais uma carta branca para invadir e remover materiais genéticos de ambientes de "outros povos”. Muitas das reações são conseqüências do impasse criado pelos esforços para o "manejo" global pela Convenção da Biodiversidade. Em outros setores, a manipulação genética é defendida pelos pesquisadores médicos que investigam maneiras de corrigir as deficiências físicas e que trabalham, inclusive, sobre uma crescente pressão pública. Cartões inteligentes, contendo impressões genéticas vitais, são previstos como equivalentes biológicos dos atuais cartões de identidade. Como as criaturas imaginadas por Aldous Huxley, habitaremos, brevemente, em um admirável mundo novo, sem sequer realmente percebermos.

Como esse cenário acima descrito influencia o meio ambiente e os discursos políticos que governam seu gerenciamento? Assim como o sujeito humano está se transformando, as noções de cidadania, de democracia e de responsabilidade também estariam se modificando? No novo mundo, a materialidade e a consciência apresentam uma crescentemente complexa relação entre si. Dada a diluição das fronteiras entre as espécies e a determinação exer- 
cida pela escolha genética sobre a política, o "meio ambiente" e a "sustentabilidade" seriam mesmo ainda categorias válidas?

\section{O SUIEITO HUMANO INFORMATIZADO}

A segunda maior transformação na maneira através da qual o meio ambiente global é construído, está associada ao desenvolvimento da tecnologia da informação e, em particular, às mudanças que estão sendo provocadas pela Internet. Essas mudanças têm estendido a circulação da informação para o centro da natureza da materialidade, já que a "realidade virtual" começa a substituir, ou a complementar a realidade material.

Quando Tim Berners-Lee inventou a Internet, ele imaginou um mundo livre da regulação, no qual a informação circularia sem impedimentos entre os vários lugares, como moedas num mercado aberto. Em certa medida, isto tem dado origem ao mito que tem seu próprio poder - o de que a Internet é "anárquica" - e é livre de forças controladoras. De muitas maneiras, isso é o oposto da realidade, já que as forças que controlam a Internet são as mesmas que controlam as sociedades humanas e o mercado.

O tipo de regulação da Internet é diferente das observados em outras instituições globais, Nestas, o controle emergiu mais de "baixo para cima" do que de "cima para baixo". A comparação com as Nações Unidas ou com a Organização Mundial do Comércio é instrutiva. O que distingue a comunicação global, via NET, é que os processos on-line começaram como processos globais, enquanto a maioria das instituições culminou na construção de seu caráter global. Como um resultado disso, foi mais fácil costurar acordos para a regulação política da Internet, o que é desconhecido pela maioria dos seus usuários.

O principal responsável pelo policiamento dos padrões de Internet é o Consórcio World Wide Web (W3C). Todavia, há um outro conjunto de instituições com inserções mais limitadas. A Internet Engineering Task Force (ITEF) desenvolve padrões técnicos acordados, tais como os protocolos de comunicação. A Internet Corporation for Assigned Names and Numbers (ICANN) mantém trilhas de nomes e números (os doze dígitos que identificam servidores conectados a endereços da Internet) e supervisiona o sistema do domínio de nomes, (tais como o .com e o .org).
Todas essas empresas foram auto-criadas e são autogovernadas. Elas são abertas em termos de membros e amplamente baseadas no consenso no que se refere à tomada de decisões.

O precursor da Internet foi a Agência de Projetos de Pesquisa Avançada do Pentágono, no final da década de 60 do século XX. Essa iniciativa foi administrada de uma maneira muito informal, o que possibilitou uma certa "igualdade" entre participantes. Na direção do processo, estavam, efetivamente, estudantes de graduação, o que justificou a afirmação de que eles criaram “... um dos primeiros processos legítimos de tomada de decisões" (The Economist, 10 de Junho de 2000). Para “pertencer” a um dos grupos planejadores das regras para a NET, era necessário apenas subscrever uma lista de e-mails. As decisões eram tomadas por consenso simples dentro dos Grupos de Trabalho. De modo semelhante, no desenvolvimento de softwares, os grupos eram formados ("Grupos-Fontes Abertos”) on-line, recebendo críticas e sugestões via rede.

Diferentemente das organizações off-line, as organizações on-line são formadas por indivíduos que pensam da mesma maneira, que dividem uma cultura comum (computacional) e interesses semelhantes. $\mathrm{O}$ que eles não partilham, como os grupos off-line, é o mesmo espaço geográfico. Defensores da "abertura" da comunicação on-line argumentam que o critério central do seu sucesso é o fato de militarem contra o "segredo" e a hierarquia. Segundo eles, esses fatos dificultam a manipulação da tomada de decisões, já que todos podem ter acesso a todas as propostas. No lugar das salas "cheias de fumaça de cigarro", a tomada de decisões sobre as comunicações virtuais acontecem no ciberespaço público.

A transparência da tomada de decisões sobre a Internet não significa que todos aqueles que a usam estão no nível de “jogar o jogo”. Já há evidências de que as questões técnicas podem estar sujeitas a pressões comerciais. Por exemplo, os proprietários de marcas comerciais têm se oposto à criação de domínios comerciais de alto nível, tais como o .com. Também há evidências do prevalecimento de interesses políticos no formato da Internet. Dois exemplos disso são: o desejo da União Européia de criar um novo domínio .eu; e a composição do W3C, que foi fundado em 1994, tendo agora 400 membros, cada um pagando cinqüenta mil dólares por ano para influenciar seus destinos.

Nada disso muda o fato de que, com a Internet, temos um novo tipo de organização global que procura

Raízes, Campina Grande, vol. 21, n0 01, p. 124-136, jan./jun. 2002 
regular a si mesma, ao invés de uma empresa que existe para regular outras organizações. Ela é expressa e conscientemente livre da interferência de governos nacionais. Resta saber quão longe as práticas e as realidades do mundo virtual irão influenciar aquelas do "mundo real". A Internet parece ser guiada pelo consenso, mas suas mensagens (codificadas e não-codificadas) são sobre o mercado e o sucesso material. Em nenhum sentido isso pode ser politicamente, ou em termos de meio ambiente neutro.

Os zapatistas, em Chiapas, foram um dos primeiros grupos a usar a Internet para uma comunicação global, superando o poder dos políticos e caciques locais. Alguns comentaristas têm argumentado que essa possibilidade de comunicação global tem servido para enfraquecer a hegemonia do mercado global. Vejamos um exemplo:

... um novo internacionalismo está em processo de auto-construção. Esse novo internacionalismo não é uma adaptação à idéia pré-concebida, a uma ideologia que serve como um fator de recomposição. Pelo contrário, a recomposição da diversidade de sujeitos sociais parece originar a necessidade prática de diferentes movimentos em suas interações dentro do contexto da economia global e em suas lutas... (DE ANGELIS, 2000: 10).

Essa linha de argumentação foi usada mais persuasivamente em relação aos protestos por ocasião das últimas reuniões da Organização Mundial do Comércio. Enquanto a OMC debatia medidas para fazer avançar a liberalização da economia, os manifestantes articulavam protestos de rua via Internet. Muitos desses protestos foram deliberativos, consensuais e politicamente articulados em comum muito mais por Organizações Não Governamentais (ONGs) do que por partidos políticos. Remetendo outra vez à argumentação de Esteva (2000), pensamos que talvez esses protestos foram mais indicativos do impulso democrático nas massas do que da força das instituições democráticas, partidos, governos e organizações internacionais, com os quais as manifestações estivesses comprometidas.

\section{CONCLUSÃO}

Esse artigo começou afirmando que ao se reconhecer que os discursos de "sustentabilidade" atingiram o centro da política ambiental internacional, é hora de dar uma pausa e examinar mais detalhadamente a agenda política e intelectual que eles propõem. Desde que o termo "desenvolvimento sustentável” foi popularizado pela Comissão Brundtland, em 1987, o ambiente natural tem estado intimamente ligado à satisfação das "necessidades" humanas. Subseqüentemente, a mudança na ênfase sobre as "necessidades" para a ênfase nos "direitos" marcou um deslocamento do poderoso paradigma keynesiano de relações econômicas internacionais, no pós-2 ${ }^{\text {a }}$ Guerra Mundial, para as certezas neoliberais do final da década de 80 e dos anos 90.

A imposição dos mercados econômicos sobre o meio ambiente global tem tanto resultados paradigmáticos quanto práticos. O foco nas "escolhas”, de indivíduos e de grupos mais amplos, expressas nas preferências de mercado, levou ao crescimento das disparidades entre as demandas políticas e sociais, e as alocações do mercado. A economia política internacional, na ortodoxia neoliberal, significou o "ajuste" econômico que precisou ser feito justamente nos países em que havia poucas provisões sociais.

A proteção ambiental e os valores que as culturas "atualmente existentes" colocam em seus ambientes foram formalmente expressos em termos de mercado e de preços. Paradoxalmente, foi a ênfase nos interesses dos indivíduos e grupos que tem levado à concentração, principalmente das ONG's, nos “direitos”, em sua oposição à globalização.

Em seguida, examinamos os discursos através dos quais a sustentabilidade, os direitos à natureza e os direitos da natureza são expressos. Sugeri que a sustentabilidade, como um conceito estabelecido, tem freqüentemente disfarçado, em vestimentas mais novas, os conflitos entre agendas do passado. Como Habermas afirma em Teoria e Prática (1971), a maneira pela qual entendemos a "natureza" atualmente é determinada pelo passado. Os "novos” discursos da sustentabilidade têm se revestido de uma nova linguagem - a deliberação, a cidadania, até mesmo os direitos das espécies - mas escondem, ou marginalizam, as desigualdades e as distinções culturais que têm determinado a agenda ambiental internacional. As questões ambientais se transformaram num objeto de políticas, sendo elaboradas por diferentes atores políticos e coalizões de discursos.

Afirmamos ainda que a invenção da necessidade de um manejo global do meio ambiente se fundamenta, em parte, no pressuposto de que ele ajudaria a corrigir as anomalias da economia e da política comercial. Duas questões específicas foram identificadas como evidência dos 
novos discursos em torno da sustentabilidade e da tentativa de incorporar nas preocupações ambientais, as questões maiores da justiça social, da governabilidade e da eqüidade.

A primeira questão está ligada ao "mantra" da globalização. Muito da preocupação com o estabelecimento de mecanismos de gerenciamento global do meio ambiente tem tomado como seu leitmotiv o desenvolvimento de "regimes" ambientais. Estes são convenções sociais frouxamente organizadas, incluindo a assinatura de acordos, que envolvem consentimento de gerenciamento ambiental global, e que são fundamentados em princípios "universais" previamente consensualizados. Os acordos internacionais que assumem a responsabilidade pelo "meio ambiente", porém, não podem reverter os efeitos da economia e dos processos sociais espacializados sobre os pobres, suas culturas e seu meio ambiente. Incapacitando individualmente os países para "administrar por si mesmos seu meio ambiente”, os acordos internacionais podem ajudar a conferir maior legitimidade ao sistema, sem que fique claro se isto é mais justo ou melhor. É também questionável se os mecanismos de mercado são apropriados, na medida em que o objetivo seria atacar os efeitos distorsivos do mercado.

A segunda questão se refere à maneira pela qual a "ciência” vem sendo utilizada para conferir legitimidade ao nosso conhecimento sobre o que está acontecendo com o meio ambiente. Essa tem sido uma marca central dos novos discursos da sustentabilidade e tem dado origem a um conjunto de coalizões políticas entre partes interessadas em negociar. Muitos desses grupos, liderados pelas ONG's (sem nem sempre conseguir), têm tentado se distanciar dos efeitos das políticas neoliberais, promovendo visões da sustentabilidade mais inclusivas, capazes de dar mais atenção à eqüidade, à justiça social e ao fortalecimento das comunidades. Em alguns casos, essas coalizões têm invocado a ciência, argumentando que o que é bom em termos ambientais é também mais justo e mais equânime. A elisão desses dois fatores - o "cientificismo" e o discurso da "justiça natural" - tem também criado confusão. Ambos podem ajudar a legitimar políticas ambientais, mas nem "ciência” nem "justiça” representam "verdades" objetivas.

Finalmente, argumentamos que a natureza crescentemente discursiva da política ambiental internacional, em suas tentativas para procurar, ou reivindicar legitimidade, apresenta outros perigos. Ela esquece o fato de que o debate natureza X cultura está sendo materialmente reescri- to através da genética e da informática. As "escalas de justiça”, com as quais as questões ambientais estão normalmente preocupadas, precisam considerar que o indivíduo humano é cada vez mais (como outras espécies) visto como um ser geneticamente modificável. Os sistemas globais de informação, disponibilizados pela Internet, têm transformado os sistemas de comunicação e a ordem simbólica, anunciando uma política nova e virtual, paralela àquela do "mundo real". É nesse sentido que os novos discursos em torno da informática e da genética podem ser vistos como discursos da "pós-sustentabilidade".

$\mathrm{O}$ artigo começou com a afirmação de que a "sustentabilidade" tem, até os dias atuais, sido uma propriedade de diferentes discursos que têm se enfrentado na arena dos interesses internacionais. Para nós, somente a exposição dos pressupostos e das conclusões desses discursos pode nos ajudar a clarear as escolhas e compromissos que envolvem a política ambiental e a abordagem das ciências sociais ambientais. Com as mudanças na materialidade e na consciência, começamos a entrar num mundo no qual a "sustentabilidade" significa novas realidades materiais, bem como novas posições epistemológicas. O desafio das ciências sociais é, portanto, identificar as maneiras pelas quais as mudanças materiais - no meio ambiente físico, nas tecnologias de informação e no corpo humano - requerem que refaçamos a idéia de sustentabilidade. São essas mudanças que futuras pesquisas devem focalizar.

\section{REFERÊNCIAS BIBLIOGRÁFICAS}

BAUMANN, Z. Globalization. Cambridge, UK: Polity Press, 1998.

BECKER E., JAHN, T. \& STEIS. Exploring Uncommon Ground: sustainability and the social sciences. In BECKER E. \& JAHN, T.(eds.). Sustainability and the Social Sciences. London: Zed Press, 1999.

BROWDER, J. Deforestation and the Environment Crisis in Latin America. In Latin American Research Review, 30 (3), 1995.

BRUNDTLAND COMISSION. Our common future. Oxford, UK: Oxford Press, 1987.

Raízes, Campina Grande, vol. 21, nº 01, p. 124-136, jan.jun. 2002 
136 Michael R. Redclift

CASTELLS, M. Material for an exploratory theory of the network society. In British Journal of Sociology, 51 (1), 2000.

DE ANGELIS. Globalisation, New Internationalism and the Zapatistas. In Capital and Class, 70, Spring, 2000.

DOBSON, A. Justice and the Environment. Oxford: Oxford University Press, 1998.

ESTEVA, G. The Zapatista's and People's Power. In Capital and Class, 68, Summer, 1999.

FINKLER, K. Experiencing New Genetics. Philadelphia: University of Pennsylvania Press, 2000.

GORE, A. Earth in the Balance. Boston: Houghlin Mifflin, 1992.

HABERMAS, J. Theory and Practice. New Left Books, 1971.

LEACH, M. \& FAIRHEAD, J. Forestry and discourse representation. In Development \& Change, 31(1), 2000.

LATOUR, B. We have never been Modern. Cambridge, Mass.: Harvard University Press, 1993.

LAW, M. \& BARNET, C. After Globalisation. In Environment and Planning D, 18(1), February, 2000.

LUKE, T. W. Environmentality as Green Governmentality. In E. DARNIER (ed.) Discourses of the Environment. Oxford: Basil Blackwell, 1999.

MCAFEE, K. Selling nature to save it? Biodiversity and green developmentalism. In Environment and Planning, D, 17 (2), 1999.

MILLER, D. Social Justice and Environmental goods. In DOBSON, A. (ed.) Fairness and Futurity. Oxford: Oxford University Press, 1998.

REDCLIFT, M. R. Wasted: counting the cost of global consumption. London: The Economist, June, 10, 2000.

VOGLER, J. The Global Commons: environmental and technological governance. $2^{\mathrm{a}}$. edição, Chichester: John Raízes, Campina Grande, vol. 21, n0 01, p. 124-136, jan./jun. 2002
Wiley, 2000.

WESTING, A. H. Towards a universal recognition of environmental responsibilities, in Environmental Conservation, 26(3) September, 1999. 